\title{
Informing Science and Andragogy: A Conceptual Scheme of Client-Side Barriers to Informing University Students
}

\author{
Linda V. Knight, Theresa A. Steinbach, and Jean D. Hop \\ DePaul University, Chicago, IL, USA
}

\author{
lknight@cdm.depaul.edu, tsteinbach@cdm.depaul.edu, \\ instrhop@gmail.com
}

\begin{abstract}
This research leverages both education and informing science research to develop a conceptual model that will assist university professors and students in identifying and overcoming barriers to informing. Since a full study of all barriers, those on the part of the informer, the channel, and the client, would be too extensive for a single paper, we focus here on client-side barriers, i.e., those inherent in the student or the student's immediate situation. We ferret out 24 specific barriers to andragogical learning from the education literature and identify 12 underlying constructs, which we categorize using the concepts of institutional, situational, and dispositional barriers from the education literature. The client-side conceptual scheme of informing specific to the domain of andragogical learning that is presented here likely has application in other informing realms, inside and outside of education. Within the realm of education, it demonstrates how education research can be viewed from an informing science perspective.
\end{abstract}

Keywords: informing science, conceptual scheme, barriers, andragogy, client, adult student, higher education, university

\section{Introduction}

The teaching of adults, or andragogy, is an important social and economic reality. Colleges and universities are applying andragogical theories to their curriculum in order to tap this rich source of students. Further, the widespread availability of the Internet, combined with the proliferation of computer technology, has heightened interest in andragogy. Burge (1988) noted that, "DL research, as opposed to traditional education research, focuses more on how adults learn.” In the latest figures from the U.S. Department of Education, Institute of Education Sciences, in 2005, 44 percent of American adults aged 17 and older participated in a program, class, or course (U.S. Department of Education, National Center for Educational Statistics, 2007). Because the continu-

Material published as part of this publication, either on-line or in print, is copyrighted by the Informing Science Institute. Permission to make digital or paper copy of part or all of these works for personal or classroom use is granted without fee provided that the copies are not made or distributed for profit or commercial advantage AND that copies 1) bear this notice in full and 2) give the full citation on the first page. It is permissible to abstract these works so long as credit is given. To copy in all other cases or to republish or to post on a server or to redistribute to lists requires specific permission and payment of a fee. Contact Publisher@InformingScience.org to request redistribution permission. ing education of adults increases the private, social, and economic value of our human capital (Lang, 2003), it is important to identify, understand, address, and overcome barriers and biases working against adult learning. In this research, we look to two fields, informing science and education, to aid in this quest. 


\section{Overview of the Goals and Methodology of this Research}

This paper does not report upon an empirical study. Rather, our goal is to combine education and informing science research to develop a conceptual model that will assist university professors and students in identifying and overcoming barriers to informing. Since a full study of all barriers, those on the part of the informer, the channel, and the client, would be too extensive for a single paper, we focus in this manuscript on the client-side barriers, i.e., those inherent in the student or the student's immediate situation. In terms of methodology, we look first at informing science research. Then we consider existing education research on teaching at the university level. Thirdly, we use research from both these domains to develop a conceptual scheme of client-side barriers to informing university students. Gill (2011b) noted that the development of a conceptual scheme has as its goal, not representing absolute truth (for that is the job of theory), but rather providing a useful way to conceptualize. Our model is designed to assist faculty and students in conceptualizing barriers to learning at the university level. After developing the model, we evaluate it by using Gill's (2011b) principle that defines usefulness as the intersection of three characteristics: relevant, acceptable, and potentially actionable. Finally, we conclude with a consideration of the contributions, limitations, and future implications of this work.

\section{A Note about Terminology}

While the education literature speaks primarily of barriers, the informing science literature also uses the term filters. Similarly, where the education literature speaks of a teacher, faculty member, or instructor, the informing science literature uses the term informer. Where the education literature speaks of educational technology, learning management systems, and specific methods or pedagogies, the informing science literature refers to channels. Since this research is focused on the intersection of informing science and education, we use these sets of terms interchangeably, relying more on traditional education terminology when discussing education and on informing science terminology when discussing informing science.

\section{Background: Barriers in Informing Science}

Informing science has been defined as "a trans-disciplinary study of systems that employ information to impact clientele” (Gill, 2011a). Note that clientele are not passive recipients of information; as Gill noted in the same address, most informing is both reciprocal and iterative.

\section{Nature of Barriers and Bias in Informing}

Barriers to informing may be defined as anything that leads to misinformation or disinformation. Cohen (2000a) defines four types of errors that lead to failure to inform: data transcription or intentional data misrepresentation, errors in data interpretation, errors related to solving the wrong problem, and filtering errors. We are concerned with the latter type here. Cohen (2000a, 2000b, 2007) categorizes filtering errors into four subtypes, as shown in Table 1. 
Knight, Steinbach, \& Hop

Table 1: Filtering types, adapted from Cohen (2000a, 2000b, 2007)

\begin{tabular}{|l|l|l|}
\hline Category & $\begin{array}{l}\text { What is being fil- } \\
\text { tered }\end{array}$ & Description \\
\hline Designer bias & Data & Designer bias in determining what data is presented \\
\hline Designer bias & Processes & $\begin{array}{l}\text { Designer bias in determining how data is processed and } \\
\text { presented }\end{array}$ \\
\hline End user bias & Data & $\begin{array}{l}\text { Bias of the end user that determines how accurately the } \\
\text { data presented is viewed }\end{array}$ \\
\hline Data smog & Data & Overwhelming amounts of information (Shenk, 1997) \\
\hline
\end{tabular}

As Cohen's work indicates, a prevalent type of barrier to successful informing is bias. Within the context of informing science, bias has been widely defined as an ever-present part of human psychology that acts as a barrier to informing. Cohen notes that the informing science framework provides for "explicit understanding of the limitations, that is, the 'fragility' of the informer, the channel (including encoding for transmission across media and resultant decoding, all in the presence of noise), and the information client. These fragilities include, but are not limited to, human limitations in perception and processing, biases due to prior knowledge, skills, abilities, and information format preferences" (Cohen, 2009). Such bias may well be unavoidable. "Among living entities, one cannot even expect informing to be objective as it always explicitly and/or implicitly is biased by purpose, emotions, and ignorance of the informing entities and entities informed” (Gackowski, 2010).

There is general agreement in the informing science literature that bias can lead to misleading or erroneous informing. However, there is disagreement about the exact definition of bias, especially with respect to whether or not the participant in an informing exchange is aware of his or her bias. In particular, Bednar and Welsh (2008) cite Cohen (2005) as saying bias is "personal inclination or preference to favor a viewpoint with failure to fully inform a direct consequence." Bednar and Welsh (2008) themselves, on the other hand, describe bias as "attempts to distort or mislead to achieve a certain perspective, i.e. subjective descriptions intended to mislead." This viewpoint clearly attributes bias to intentional acts on the part of the information sharer. On the other hand, Stahl (2006) leans more toward Cohen's definition, in that the former sees bias as "unacknowledged personal conviction" and notes it likely is a basis for mis-information, i.e., wrong or misleading information that Stahl distinguishes from dis-information by noting that the informer is unaware of its erroneous nature.

Gackowski (2006) takes a more philosophical approach to describing bias, noting "the natural tendency of anything living toward bias and outright disinformation.” This is a concept that Cohen had noted as early as 2000 (Cohen, 2000a). However, Gackowski goes further, explaining that Will, defined by Schopenhauer as the driving force behind all nature, is the inevitable source of bias and disinformation. Gackowski notes that this bias may be countered to some extent by increasing credibility through the use of a variety of different informing sources. Further, he recommends identifying any commonality or disparity between the information source and the informed entity, along with any history of bias in their prior relationship. As shown in Table 2, verifiability, replicability, and warranty are all seen by Gackowski as ways to increase credibility and lessen risk to the informed entity. 
Table 2: Measures of source-specific credibility, adapted from Gackowski (2006)

\begin{tabular}{|l|l|l|}
\hline Verifiability & Replicability & Warranty \\
\hline $\begin{array}{l}\text { External review, including } \\
\text { auditing and accreditation. }\end{array}$ & $\begin{array}{l}\text { Allowing for additional or } \\
\text { confirmatory testing. }\end{array}$ & $\begin{array}{l}\text { Stronger warranties lessen } \\
\text { the informed entity's risk. } \\
\text { Bonds strengthen warranties. }\end{array}$ \\
\hline
\end{tabular}

Thus at least three major issues concerning the nature of bias emerge from the informing science literature. One is the question of whether bias is intentional or unconscious. Another is whether bias is an unavoidable, ever-present part of the human condition. A third is whether bias should be studied from the standpoint of the informer, the client, or both. Kalyuga (2011) would argue that both are important, noting that "The information structures of both informers and clients provide natural sources of bias and misinformation in the process of informing, including a breakdown in the informing process in case of fundamental differences between their information structures.” Further, bias can exist within the channel (Gill, 2008b). Although bias can be present in the informer, channel, or client, we are focusing here on the client, and in particular on unintentional bias that creeps into the process of informing within the adult education domain.

\section{Bias in the Client}

Cohen (2007) noted that in order for an information system to effectively "select, process, sequence, and format" information, its designer must understand three things: the client's problem, the client's current knowledge and uncertainties, and the client's information seeking preferences. This approach clearly infers the need for a symbiotic relationship between the designer of the information system and the client. In our education domain, it demands a close, ongoing relationship between teacher and student. Gill's (2011b) interests were primarily on the student or client side. He noted that filters can change, amplify, or inhibit the information being sent to the client. He further noted that these barriers can be related to clients' mental models and motivation. Much of his 2011 work is based in earlier work by Jamieson and Hyland (2006), which we explore now, before going more deeply into Gill's research.

Jamieson and Hyland's (2006) work on bias in information system decision making concentrates on bias inherent in the client. They identify four types of biases "that affect decision making and are prevalent in the literature.” These are summarized in Table 3.

Table 3: Types of biases affecting decision-making, adapted from Jamieson and Hyland (2006)

\begin{tabular}{|l|l|l|}
\hline Bias & Description & Examples \\
\hline $\begin{array}{l}\text { Information Bi- } \\
\text { ases }\end{array}$ & $\begin{array}{l}\text { Distortions of information and how it is } \\
\text { weighted. }\end{array}$ & $\begin{array}{l}\text { Wishful thinking. } \\
\text { The desire to reduce effort. }\end{array}$ \\
\hline Cognitive Biases & $\begin{array}{l}\text { Ways decision-makers attempt to reduce } \\
\text { cognitive load and simplify the informa- } \\
\text { tion they are required to process. }\end{array}$ & $\begin{array}{l}\text { Reasoning by analogy. } \\
\text { Allusion of control. } \\
\text { Escalating commitment. } \\
\text { Single-outcome calculation. }\end{array}$ \\
\hline Risk Biases & $\begin{array}{l}\text { Biases that avoid rating options based on } \\
\text { both potential risk and potential gain/loss. }\end{array}$ & $\begin{array}{l}\text { Risk aversion. } \\
\text { Risk seeking. }\end{array}$ \\
\hline $\begin{array}{l}\text { Uncertainty Bi- } \\
\text { ases }\end{array}$ & $\begin{array}{l}\text { Biases designed to give the sense of re- } \\
\text { ducing uncertainty. }\end{array}$ & $\begin{array}{l}\text { Seeking increased informa- } \\
\text { tion, which results in informa- } \\
\text { tion overload. }\end{array}$ \\
\hline
\end{tabular}


According to Jamieson and Hyland (2006), “... bias is a function of the contextual influences such as organisational culture, organisational history, organisational relationships, internal organisational structures, politics, composition of the decision making body and organisational size.” Further, bias may have positive or negative influences on decision-making, depending to some degree on such factors as level of uncertainty, rigor, and transparency in decision-making (Jamieson \& Hyland, 2006). The influence of bias in an informing system, as defined by Jamieson and Hyland, is shown in Figure 1. Note that the four identified biases influence one another as well as the decision making process itself.

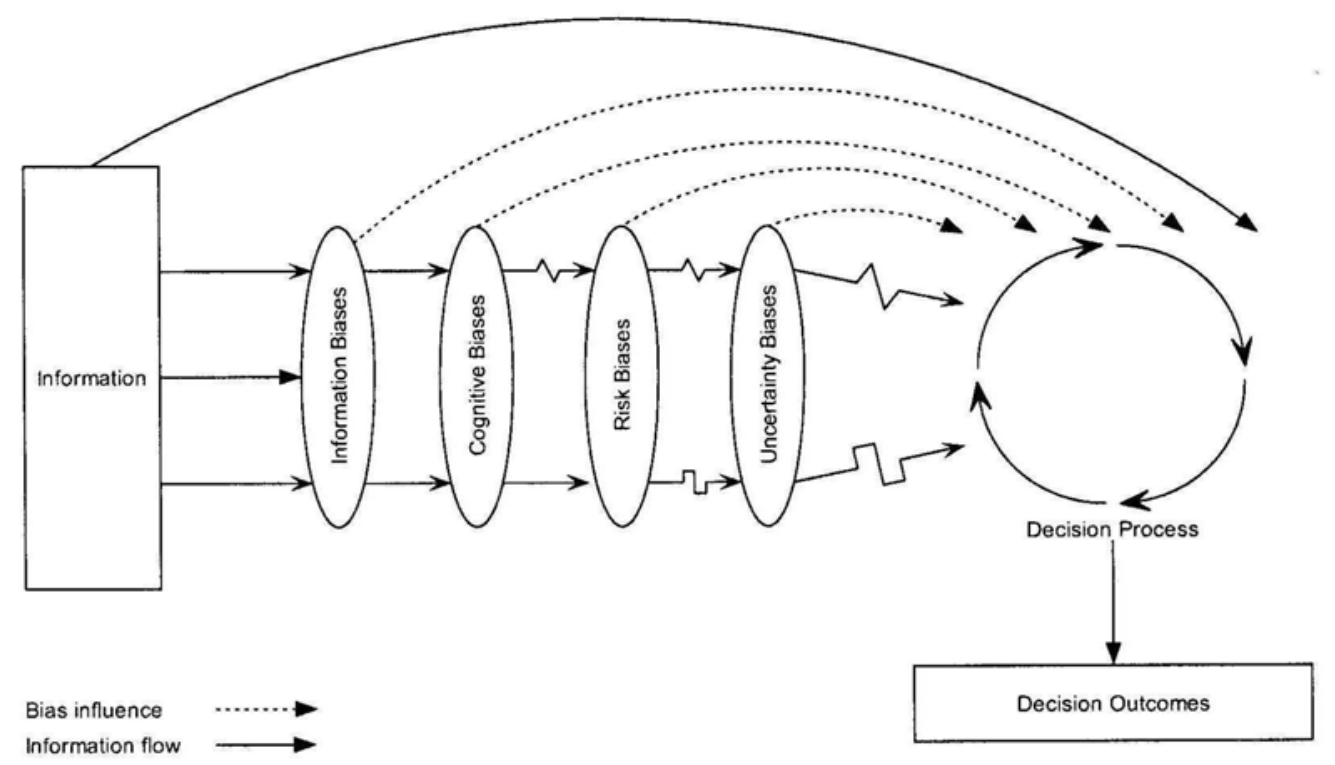

Figure 1. Bias in an informing system, from Jamieson \& Hyland (2006)

Gill (2008b), building upon the work of Jamieson \& Hyland (2006), also focused on bias with respect to the client, and developed the Client Resonance Model, shown in Figure 2. Implicit in this model is the concept that six client filters are responsible for biasing the way information is received and processed. These filters may change the strength or the perceived content of the information. The six filters are:

1) Attention Filter: Determines whether client will allow information to be received. "This filter, it is assumed, will depend heavily on motivational and visceral elements of the informing situation.” (Gill, 2008b)

2) Information Filter: From the Jamieson and Hyland model

3) Cognitive Filter: From the Jamieson and Hyland model

4) Risk and Time Filter: "The "risk biases” filter (author insert: from the Jamieson and Hyland model) is generalized as the "risk and time preference" filter. This reflects the fact that attitudes towards risk and time often lead to similar effects and anomalies (Gill, 2008a). It is also consistent with some biological evidence that delayed and uncertain outcomes employ common circuitry in the brain (Politser, 2008, p. 54).

5) Motivation Filter: "This filter specifically addresses the aspects of the motivational context of the informing that are directly related (i.e., intrinsic) to the task that is the object of the informing." (Gill, 2008b) 
6) Visceral Factors Filter: "This filter addresses motivational issues that extend beyond the task and, more generally, to the overall impact in informing of visceral factors, which include drives (e.g., hunger, thirst), moods, emotions, and pain” (Gill, 2008b).

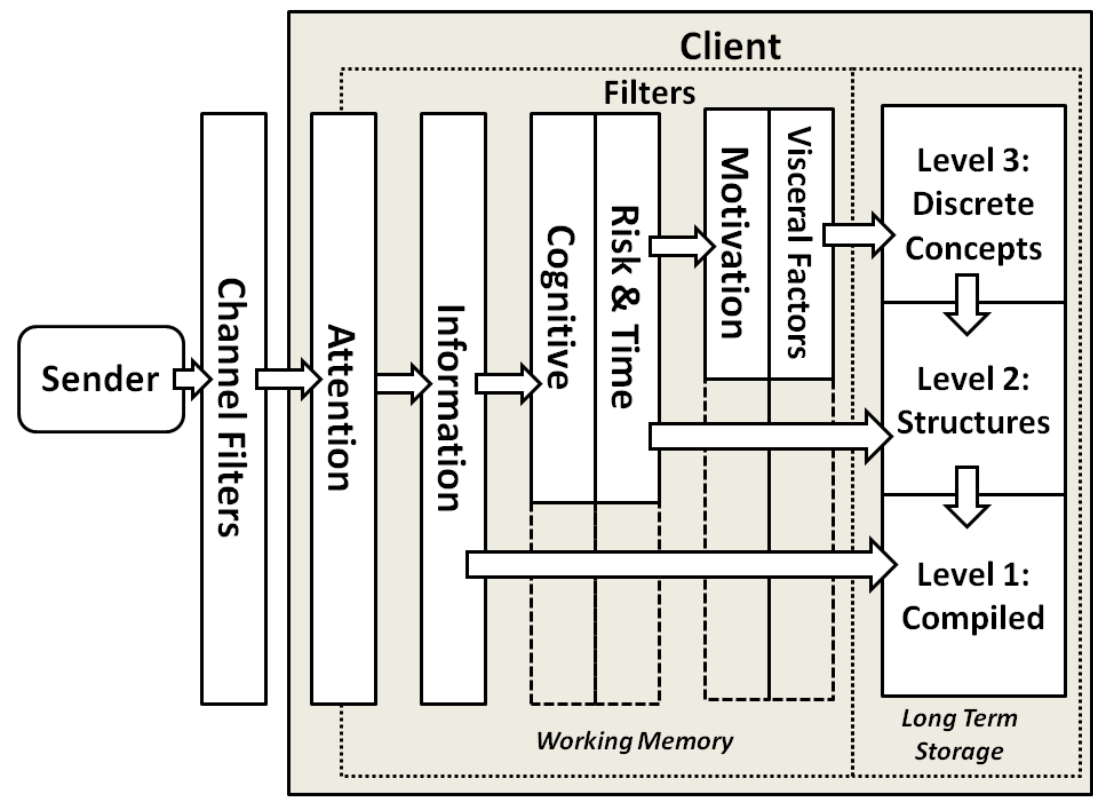

Figure 2. Client Resonance Model, from Gill (2010).

Gill's model incorporates three levels of task-specific knowledge:

\section{Level 1 - Compiled:}

High level concepts and principles where few work.

\section{Level 2 - Structures:}

Academics often work in this space, generally covering a broader set of cases than practitioners working at Level 1.

\section{Level 3 - Concepts:}

Knowledge resulting from regular repetition of a small number of tasks. This type of knowledge can be used to perform tasks with little or no conscious attention. Practitioners work in this space.

Gill sees his Client Resonance Model as more of a research agenda than a theory. In addition, he recognizes the existence of channel filters although they are not the focus of this work. Further, he notes that his model is designed for an informing environment where the informer has both well-understood information to send and some depth of understanding of the mental status of the client. With this informing science background, we now turn to examine the education literature, looking first at the major theories of teaching and learning, and then focusing on the specific barriers inherent in andragogy. 


\section{Background - Client-Side Barriers to Educating University Students}

\section{Learning Theory}

Learning "products" and the process of learning fall into four main categories: Behaviorist, Cognitivist, Humanist, and Social and Situational. Each of these educational philosophies has a different view of the purpose of learning, of the learning process, of the instructor's role, and of the student's role. Each has its own proponents and detractors. All are accepted theories. Table 4 outlines the specifics of each category. This table was adapted from a similar table developed by The Encyclopaedia of Informal Education based upon the work of Merriam and Caffarella (Smith, 2011b).

Table 4: Summary of four major learning theories (see text for derivation of table)

\begin{tabular}{|c|c|c|c|c|}
\hline --------------------- & Behaviorist & Cognitivist & Humanist & $\begin{array}{l}\text { Social \& Situ- } \\
\text { ational }\end{array}$ \\
\hline $\begin{array}{l}\text { Learning theo- } \\
\text { rists }\end{array}$ & $\begin{array}{l}\text { Thorndike, Pavlov, } \\
\text { Watson, Guthrie, } \\
\text { Hull, Tolman, } \\
\text { Skinner }\end{array}$ & $\begin{array}{l}\text { Koffka, Kohler, } \\
\text { Lewin, Piaget, } \\
\text { Ausubel, Bruner, } \\
\text { Gagne }\end{array}$ & Maslow, Rogers & $\begin{array}{l}\text { Bandura, Lave and } \\
\text { Wenger, Salomon }\end{array}$ \\
\hline $\begin{array}{l}\text { View of the } \\
\text { learning process }\end{array}$ & $\begin{array}{l}\text { Change in behav- } \\
\text { iour }\end{array}$ & $\begin{array}{l}\text { Internal mental } \\
\text { process (including } \\
\text { insight, informa- } \\
\text { tion processing, } \\
\text { memory, percep- } \\
\text { tion) }\end{array}$ & $\begin{array}{l}\text { A personal act to } \\
\text { fulfill potential }\end{array}$ & $\begin{array}{l}\text { Interaction } \\
\text { /observation in so- } \\
\text { cial contexts. } \\
\text { Movement from the } \\
\text { periphery to the } \\
\text { centre of a commu- } \\
\text { nity of practice }\end{array}$ \\
\hline $\begin{array}{l}\text { Locus of learn- } \\
\text { ing }\end{array}$ & $\begin{array}{l}\text { Stimuli in external } \\
\text { environment }\end{array}$ & $\begin{array}{l}\text { Internal cognitive } \\
\text { structuring }\end{array}$ & $\begin{array}{l}\text { Affective and } \\
\text { cognitive needs }\end{array}$ & $\begin{array}{l}\text { Learning is in rela- } \\
\text { tionship between } \\
\text { people and envi- } \\
\text { ronment }\end{array}$ \\
\hline $\begin{array}{l}\text { Purpose in edu- } \\
\text { cation }\end{array}$ & $\begin{array}{l}\text { Produce behavioral } \\
\text { change in desired } \\
\text { direction }\end{array}$ & $\begin{array}{l}\text { Develop capacity } \\
\text { and skills to learn } \\
\text { better }\end{array}$ & $\begin{array}{l}\text { Become self- } \\
\text { actualized, } \\
\text { autonomous }\end{array}$ & $\begin{array}{l}\text { Full participation in } \\
\text { communities of } \\
\text { practice and utiliza- } \\
\text { tion of resources }\end{array}$ \\
\hline Educator's role & $\begin{array}{l}\text { Arranges environ- } \\
\text { ment to elicit de- } \\
\text { sired response }\end{array}$ & $\begin{array}{l}\text { Structures content } \\
\text { of learning activity }\end{array}$ & $\begin{array}{l}\text { Facilitates de- } \\
\text { velopment of the } \\
\text { whole person }\end{array}$ & $\begin{array}{l}\text { Works to establish } \\
\text { communities of } \\
\text { practice in which } \\
\text { conversation and } \\
\text { participation can } \\
\text { occur }\end{array}$ \\
\hline Student's role & $\begin{array}{l}\text { Observe and in- } \\
\text { corporate learning } \\
\text { activities into be- } \\
\text { havioral } \\
\text { changes/models }\end{array}$ & $\begin{array}{l}\text { Explore with oth- } \\
\text { ers in a personally } \\
\text { meaningful way }\end{array}$ & $\begin{array}{l}\text { Use learning to } \\
\text { develop person- } \\
\text { ally }\end{array}$ & $\begin{array}{l}\text { Communally inter- } \\
\text { act with others to } \\
\text { share knowledge }\end{array}$ \\
\hline $\begin{array}{l}\text { Evidence of } \\
\text { successful learn- } \\
\text { ing }\end{array}$ & Behavior change & $\begin{array}{l}\text { Application of } \\
\text { knowledge }\end{array}$ & Personal growth & $\begin{array}{l}\text { Knowledge transfer } \\
\text { within community }\end{array}$ \\
\hline
\end{tabular}


The role of the student varies with the philosophy of learning. Behaviorists believe students observe as their method of learning and manifest learning in changed behaviors. Cognitivists believe students should explore with peers in an environment structured by their teacher. In the humanist view, students actively engage their feelings, particularly about themselves, and use learning activities to develop their individual human potential. Finally, from the perspective of social and situational learning, students interact socially with the community, learning from knowledgeable members. Thus the education literature gives us four unique ways of viewing the teaching and learning process. We now turn our attention to andragogy.

\section{Andragogy}

The term andragogy was first used in a published work (Platon's Erziehungslehre (Plato's Educational ideas)) in 1833 (Mitchell, 2006). Written by German high school teacher, Alexander Kapp (as cited in Smith, 2011a), this book documented lifelong learning, beginning with childhood (pedagogy) and proceeding through adulthood (andragogy.) The term andragogy initially was used only intermittently to refer to formal and informal adult education. Then Malcolm Knowles (1968) used it in his ground breaking article Andragogy, not Pedagogy. This article established andragogy as an educational discipline of its own (Reischmann, 2005).

In The Modern Practice of Adult Education from Pedagogy to Andragogy, Knowles (1973) posits adult learners differed from younger learners in four important areas:

These assumptions are that as individuals mature: 1) their self-concept moves from one of being a dependent personality toward being a self-directed human being; 2) they accumulate a growing reservoir of experience that becomes an increasingly rich resource for learning; 3) their readiness to learn becomes oriented increasingly to the developmental tasks of their social roles; and 4) their time perspective changes from one of postponed application of knowledge to immediacy of application, and accordingly, their orientation toward learning shifts from one of subject-centeredness to one of performancecenteredness. (p. 44)

Carl Rogers (1969), developer of the Experiential Learning Theory of Adult Education, believed adults benefitted from education and training that was dynamic, anecdotal, relevant, and experiential. He wrote, "Adult Learners have specific needs that stem from the way we learn. We learn by taking risks and sharing our experiences with our peers.” The Learning Process Model put forth by Peter Jarvis (1995) describes reflective learning. A form of Rogers' Experiential Learning, reflective learning involves adults learning through social and sensory experiences, for example utilizing real life case studies and journal reflections. The adults' sense of independence and their place in the social scheme determine adult motivations to learn. Transformational Learning, a theory by Jack Mezirow (1997), says learning must change the student and is a combination of student experiences, critical reflections, and class discussion. Patricia Cranton (2002) took Transformational Learning one step further and incorporated Jung personality theory with it, by considering the role personality plays in filtering the information the student receives. Jane Vella's Dialogue Education model takes the view the teacher and students are equals in a classroom and a student learns through discussion and participation in class (2002). Vella's theory says the learner decides what needs to be learned and respect for the learner is paramount to success. Learning comes through ideas, feelings, and actions with reflection and it must take place in a "safe" environment.

As the preceding discussion demonstrates, theories about adult learning abound. These theories are not always mutually exclusive and routinely borrow aspects from other existing theories, including the behaviorist, cognitivist, humanist, and social and situational theories of education. Many elements such as the role of the student's life experiences in learning, the recognition of the 
value of the student as a person, the importance of active participation in learning, and the internal motivation of the student are present in multiple theories.

\section{Barriers to Adult Learning}

\section{Identification of Major Barriers}

Using the education literature, we identified 26 distinct barriers to adult learning (Knight, Hop, \& Steinbach, 2012). These are shown in Table 5.

Table 5: Barriers to andragogical learning, adapted from Knight et al., 2012

\begin{tabular}{|c|c|c|c|c|c|}
\hline Barrier & Researcher(s) & Barrier & Researcher(s) & Barrier & Researcher(s) \\
\hline $\begin{array}{l}\text { Classes not } \\
\text { available }\end{array}$ & $\begin{array}{l}\text { Mungania } \\
\text { (2003) }\end{array}$ & $\begin{array}{l}\text { Family obliga- } \\
\text { tions; Lack of } \\
\text { child care }\end{array}$ & $\begin{array}{l}\text { Muilenburg \& } \\
\text { Berge (2005); } \\
\text { Kimmel \& } \\
\text { McNeese } \\
\text { (2006) }\end{array}$ & $\begin{array}{l}\text { Insufficient } \\
\text { computer } \\
\text { literacy }\end{array}$ & $\begin{array}{l}\text { Taylor \& Rose } \\
\text { (2005) }\end{array}$ \\
\hline $\begin{array}{l}\text { Institution } \\
\text { technology } \\
\text { not working }\end{array}$ & Galusha (1997) & $\begin{array}{l}\text { Family value } \\
\text { for education }\end{array}$ & $\begin{array}{l}\text { Mungania } \\
\text { (2003); } \\
\text { McCarthy \& } \\
\text { Berger (2008) }\end{array}$ & $\begin{array}{l}\text { Entering non- } \\
\text { traditional } \\
\text { role }\end{array}$ & $\begin{array}{l}\text { Morris \& } \\
\text { Daniel (2008) }\end{array}$ \\
\hline $\begin{array}{l}\text { Difficult to } \\
\text { access re- } \\
\text { quired in- } \\
\text { formation }\end{array}$ & $\begin{array}{l}\text { Muilenburg \& } \\
\text { Berge (2005) }\end{array}$ & $\begin{array}{l}\text { Insufficient } \\
\text { entry level } \\
\text { knowledge }\end{array}$ & DeVito (2009) & $\begin{array}{l}\text { Lack of en- } \\
\text { joyment of } \\
\text { learning } \\
\text { process }\end{array}$ & $\begin{array}{l}\text { Muilenburg \& } \\
\text { Berge (2005) }\end{array}$ \\
\hline $\begin{array}{l}\text { Lack of } \\
\text { institutional } \\
\text { support for } \\
\text { tutoring }\end{array}$ & $\begin{array}{l}\text { Silva, Cahalan, } \\
\text { \& Lacireno- } \\
\text { Paquet (1998) }\end{array}$ & $\begin{array}{l}\text { Health con- } \\
\text { cerns }\end{array}$ & $\begin{array}{l}\text { Silva, Cahalan, } \\
\text { \& Lacireno- } \\
\text { Paquet (1998) }\end{array}$ & $\begin{array}{l}\text { Accessibility } \\
\text { due to age }\end{array}$ & $\begin{array}{l}\text { Taylor \& Rose } \\
\text { (2005) }\end{array}$ \\
\hline $\begin{array}{l}\text { Lack of } \\
\text { technical } \\
\text { assistance }\end{array}$ & $\begin{array}{l}\text { Muilenburg \& } \\
\text { Berge (2005) }\end{array}$ & $\begin{array}{l}\text { Inconvenient } \\
\text { class time }\end{array}$ & DeVito (2009) & $\begin{array}{l}\text { Classes not } \\
\text { relevant }\end{array}$ & Galusha (1997) \\
\hline $\begin{array}{l}\text { Lack of } \\
\text { institutional } \\
\text { guidance }\end{array}$ & $\begin{array}{l}\text { Timarong, } \\
\text { Temaungil \& } \\
\text { Sukrad (2002) }\end{array}$ & $\begin{array}{l}\text { Inconvenient } \\
\text { class location }\end{array}$ & DeVito (2009) & $\begin{array}{l}\text { Confidence } \\
\text { level of stu- } \\
\text { dent }\end{array}$ & $\begin{array}{l}\text { Kimmel \& } \\
\text { McNeese } \\
\text { (2006) }\end{array}$ \\
\hline $\begin{array}{l}\text { Cultural } \\
\text { value of } \\
\text { education }\end{array}$ & $\begin{array}{l}\text { McCarthy \& } \\
\text { Berge (2008) }\end{array}$ & $\begin{array}{l}\text { Lack of em- } \\
\text { ployer support }\end{array}$ & Galusha (1997) & $\begin{array}{l}\text { Personal ma- } \\
\text { turity }\end{array}$ & Titus (1999) \\
\hline $\begin{array}{l}\text { High cost of } \\
\text { education }\end{array}$ & $\begin{array}{l}\text { Kimmel \& } \\
\text { McNeese } \\
\text { (2006) }\end{array}$ & Lack of time & $\begin{array}{l}\text { Silva, Cahalan, } \\
\text { \& Lacireno- } \\
\text { Paquet (1998) }\end{array}$ & $\begin{array}{l}\text { Program du- } \\
\text { ration too } \\
\text { long }\end{array}$ & DeVito (2009) \\
\hline Weather & $\begin{array}{l}\text { Silva, Cahalan, } \\
\text { \& Lacireno- } \\
\text { Paquet (1998) }\end{array}$ & $\begin{array}{l}\text { Transportation } \\
\text { problems; } \\
\text { High cost of } \\
\text { transportation }\end{array}$ & $\begin{array}{l}\text { Silva, Cahalan, } \\
\text { \& Lacireno- } \\
\text { Paquet (1998) }\end{array}$ & $\begin{array}{l}\text { Competing } \\
\text { information }\end{array}$ & $\begin{array}{l}\text { Gill (2010); } \\
\text { Bain (2004); } \\
\text { Halhoun \& } \\
\text { Hestenes } \\
\text { (1985) }\end{array}$ \\
\hline
\end{tabular}




\section{Categorizing Barriers to Adult Learning}

Given these barriers, we looked again to the education literature for assistance in categorizing them. According to Blum (1999), andragogical barriers can be divided into three categories: institutional, situational, and dispositional. Descriptions of these three categories follow:

1. Institutional barriers are the result of standard practices by universities. These may include technical difficulties in access to information or excessive university regulation (Galusha, 1997). One example of an institutional barrier is the requirement that a student file the Free Application for Federal Student Aid (FAFSA) form to request financial aid. The student might find the task overwhelming in its time and information requirements and simply not file it. Institutional barriers are outside the student's span of control but require expenditures of resources.

2. Situational barriers relate to “one's situation in life at a given time” (Blum, 1999). These can include family life, financial costs, and limited employer support (Galusha, 1997). All these barriers have in common the fact that they are experienced differently depending upon the individual. Blum (1999) notes that barriers related to family life can be of particular interest to female students.

3. Dispositional barriers relate to student self-perceptions and attitudes. These are internal to the student. Perceptions, by definition, are not based on any actual reality but people act upon them as if they were facts (Klein, Noe, \& Wang, 2006). Negative perceptions can result in increased dropout rates, lower motivation to learn, and overall lower student satisfaction in the learning experience (Klein et al., 2006). Examples of dispositional barriers are personal evaluations as to ability to succeed in a given class, the ability to use the technology required to be successful, and a student's personal evaluation of the expertise of the instructor.

\section{A New Categorization Matrix for Educational Barriers}

Some of the barriers that we had identified previously did not align with any of Blum's categories. In particular, environmental barriers, like weather, that did not arise from the university did not fit the categorization scheme. Therefore, we broadened the definition of institutional barriers to include all barriers external to the student and experienced similarly by most students. This allowed us to develop a new definition for each barrier category based on two primary criteria: whether the barrier is external or internal to the individual and whether most individuals experience the barrier in more-or-less the same way. This approach led us to the following updated definitions for categories of educational barriers:

1. Institutional: barriers external to the individual are experienced similarly by most individuals.

2. Situational: barriers external to the individual are experienced differently by individuals.

3. Dispositional: barriers internal to the individual are experienced differently by individuals.

Thus, we propose a new matrix for classifying educational barriers, as shown in Figure 3. This arrangement, which we call the Educational Barrier Matrix, provides a rapid way of properly categorizing barriers to learning. 


\section{Internal to Individual}

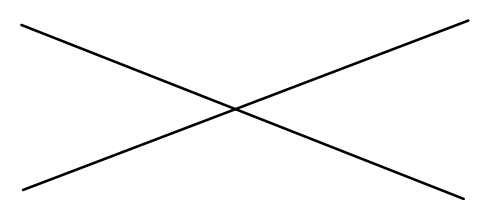

DISPOSITIONAL
External to Individual

\section{INSTITUTIONAL}

Individuals

experience

differently

\section{SITUATIONAL}

Figure 3: Educational Barrier Matrix

Using our Educational Barrier Matrix along with the previously cited educational research, we proceeded to categorize the major barriers to adult learning, as identified previously in Table 5. Results are shown in Table 6 .

Table 6: Barriers by category

\begin{tabular}{|c|c|}
\hline Category & Barrier \\
\hline \multirow{4}{*}{ Institutional } & Classes not available \\
\hline & Institution technology not functioning correctly \\
\hline & Difficult to access required information \\
\hline & Lack of institution support for tutoring \\
\hline \multirow{4}{*}{$\begin{array}{l}\text { Institutional, } \\
\text { continued }\end{array}$} & Lack of technical assistance \\
\hline & Lack of institutional guidance \\
\hline & High cost of education-tuition, books, materials \\
\hline & Weather \\
\hline \multirow[t]{10}{*}{ Situational } & Family obligations \\
\hline & Lack of child care \\
\hline & Cultural or family value for education \\
\hline & Insufficient entry level knowledge \\
\hline & Insufficient computer literacy \\
\hline & Health concerns \\
\hline & Accessibility due to age \\
\hline & Inconvenient class time \\
\hline & Inconvenient class location \\
\hline & Lack of employer support \\
\hline
\end{tabular}




\begin{tabular}{|l|l|}
\hline Category & Barrier \\
\hline \multirow{4}{*}{ Dispositional } & Lack of time \\
\cline { 2 - 3 } & Transportation problems \\
\cline { 2 - 3 } & High cost of transportation \\
\cline { 2 - 2 } & Entering non-traditional role \\
\cline { 2 - 2 } & Confidence level of student \\
\cline { 2 - 2 } & Personal maturity \\
\cline { 2 - 2 } & Classes not relevant \\
\cline { 2 - 2 } & Program duration too long \\
\cline { 2 - 2 } & Competing information \\
\hline
\end{tabular}

\section{Refining the Barrier Categories}

Once we identified the major barriers and categorized them as institutional, situational, or dispositional, we then considered each barrier category one at a time, with the goal of unearthing underlying constructs. Results of this analysis are shown in Table 7, Barrier Types. Notably, the original eight institutional barriers were consolidated into four categories, the 14 situational barriers were consolidated into four categories, and the six dispositional barriers were consolidated into four categories. Thus, through the process of applying our Educational Barriers Matrix, we were able to condense the original list of 28 barriers to 12 constructs. These are the 12 primary barriers to adult learning, as shown in Table 8.

Table 7: Barrier Types

\begin{tabular}{|c|c|c|}
\hline Category & Barrier & Classification / Type of Barrier \\
\hline \multirow{8}{*}{ Institutional } & High cost of education-tuition, books, materials & Cost \\
\hline & Classes-not available & Support \\
\hline & $\begin{array}{l}\text { Lack of institution support for tutoring - class } \\
\text { material }\end{array}$ & Support \\
\hline & $\begin{array}{l}\text { Lack of institutional guidance - classes to take, } \\
\text { requirements to be met, etc. }\end{array}$ & Support \\
\hline & Lack of technical assistance & Support \\
\hline & Difficult to access required information & Support, Technology \\
\hline & Institution technology not functioning correctly & Technology \\
\hline & Weather & Weather \\
\hline \multirow[t]{3}{*}{ Situational } & Cultural or family value for education & Cultural considerations \\
\hline & Entering non-traditional role & Cultural considerations \\
\hline & Inconvenient-class time & $\begin{array}{l}\text { Personal environment, Learning envi- } \\
\text { ronment }\end{array}$ \\
\hline
\end{tabular}




\begin{tabular}{|c|c|c|}
\hline Category & Barrier & Classification / Type of Barrier \\
\hline & Inconvenient-location & $\begin{array}{l}\text { Personal environment, Learning envi- } \\
\text { ronment }\end{array}$ \\
\hline & $\begin{array}{l}\text { Insufficient background (entry level knowledge } \\
\text { and computer literacy) }\end{array}$ & $\begin{array}{l}\text { Prior knowledge, Learning environ- } \\
\text { ment }\end{array}$ \\
\hline & Lack of time & Personal environment \\
\hline & Lack of employer support & Personal environment \\
\hline & $\begin{array}{l}\text { Transportation problems, High cost of transpor- } \\
\text { tation }\end{array}$ & Personal environment \\
\hline & Family obligations, Lack of available child care & Personal environment \\
\hline & Health concerns, Accessibility due to age & Personal environment \\
\hline \multirow{6}{*}{ Dispositional } & Classes not relevant & $\begin{array}{l}\text { Perceived program value, Perception } \\
\text { of sender / informer }\end{array}$ \\
\hline & Program duration too long & Perceived program value \\
\hline & Lack of enjoyment of learning process & $\begin{array}{l}\text { Perceived program value, Perception } \\
\text { of sender, Perception of channel }\end{array}$ \\
\hline & Confidence level of student & Self-image \\
\hline & Personal maturity & Self-image \\
\hline & Competing information & $\begin{array}{l}\text { Perceived program value, Perception } \\
\text { of sender / informer }\end{array}$ \\
\hline
\end{tabular}

\section{Descriptions of the Barrier Sets}

The source of institutional barriers is external to the individual but affects most individuals in similar ways. Examples include the cost of education, including tuition, books, and materials, and the weather. Hurricanes, tornadoes, and unusually large amounts of snowfall have closed campuses around the world. In another example, most institutions rely on electronic media to inform students of critical dates, process enrollment, and manage coursework. If those systems do not function without error or the information is not easily found, a barrier will be created. The lack of technical assistance in resolving issues related to accessing the institution's technology may adversely impact the student's ability to enroll in required classes and participate in individual courses. The lack of institutional support for students can determine when and how successfully a degree is completed. If required courses are not offered on a timely schedule, students cannot complete the program within an acceptable timeframe. A curriculum advising staff that is not knowledgeable or is not available through multiple modes of communication can lead to a student completing courses that do not meet the requirements of the program or failing to enroll in infrequently scheduled required courses. Lack of supplemental instruction or tutor availability can impact student success. Of course, students may experience institutional barriers differently depending on their own circumstances. For example, a snowstorm is less of a barrier for a student living across the street from the university. The lack of adequate technical support is less of a barrier for a student who is a computer expert. Poor advising is less of a barrier for a student with older siblings at the university. Nonetheless, a snowstorm, lack of adequate technical support, and lack of suitable advising affect the majority of students similarly. This is the distinguishing characteristic of an institutional barrier. 
Like institutional barriers, the source of situational barriers is external to the individual. However, situational barriers are likely to affect each individual differently. Situational barriers include prior knowledge, cultural considerations, the learning environment, and an individual student's personal environment. Family obligations can negatively affect the time a student has to devote to his or her studies, and the pressure of family obligations can increase tremendously if a student is caring for elderly parents or extended family members, as well as his or her own children. Additionally, the cost of care for these individuals while a student attends classes becomes part of the student's educational expenses. If a family or culture does not value the pursuit of higher education, the student may feel isolated within his or her personal environment. In another example, students may enter a course without sufficient knowledge of the prerequisite material, even if they have taken the required classes. Alternatively, personal or family health concerns can affect students' ability to control the time they have available for education and decrease the amount of monies available for tuition and supplemental expenses, both key issues in the students' personal environment. If classes are held at an inconvenient time or location for an individual student, the inability to complete required courses may adversely impact degree progress. The lack of employer support, e.g., not allowing a student to work a flexible schedule in order to attend class, will impede degree completion. The cost of transportation to attend classes or problems associated with travel, including rush hour delay in arriving at evening classes, impacts an individual's budget and allotted time commitment.

Table 8: Framework of Barriers to Adult Learning

\begin{tabular}{|l|l|}
\hline \multirow{4}{*}{ Institutional: } & Cost \\
& $\begin{array}{l}\text { Weather } \\
\text { Support } \\
\text { Technology }\end{array}$ \\
\hline Situational: & $\begin{array}{l}\text { Prior knowledge } \\
\text { Cultural considerations } \\
\text { Learning environment } \\
\text { Personal environment }\end{array}$ \\
\hline Dispositional: & $\begin{array}{l}\text { Self-image } \\
\text { Perceived program value } \\
\text { Student's image of sender/informer } \\
\text { Student's image of channel }\end{array}$ \\
\hline
\end{tabular}

Unlike institutional and situational barriers, the source of dispositional barriers is the individual student themselves. Dispositional barriers involve the student's individual perceptions, including his or her self-image, how the student perceives the value of his educational program, as well as the image the student has of his teacher (sender or informer) and his means of learning (channel). Confidence level and maturity level of the student can mitigate the influence of situational and institutional barriers. The student's perception of the accuracy and relevancy of information presented and the perceived credibility of the sender/informer may affect the amount of time and resources a student will allocate to the class. If a student deems the timeframe to complete the program is excessive, the student may not believe there is value in aggressively pursuing degree completion. Both of these barriers, course relevancy and program length, may lead to a decrease 
in enjoyment of the learning process. The reputation and credibility of the instructor can influence the student's ability to accurately and fully receive information from that instructor. Similarly, the student's attitudes toward instructional technologies used to communicate can affect the student's learning.

\section{Conceptual Scheme}

Having identified and categorized the barriers to adult learning, we now develop our conceptual scheme. We begin with a model of the informing science process, from Cohen (2009), Figure 4.

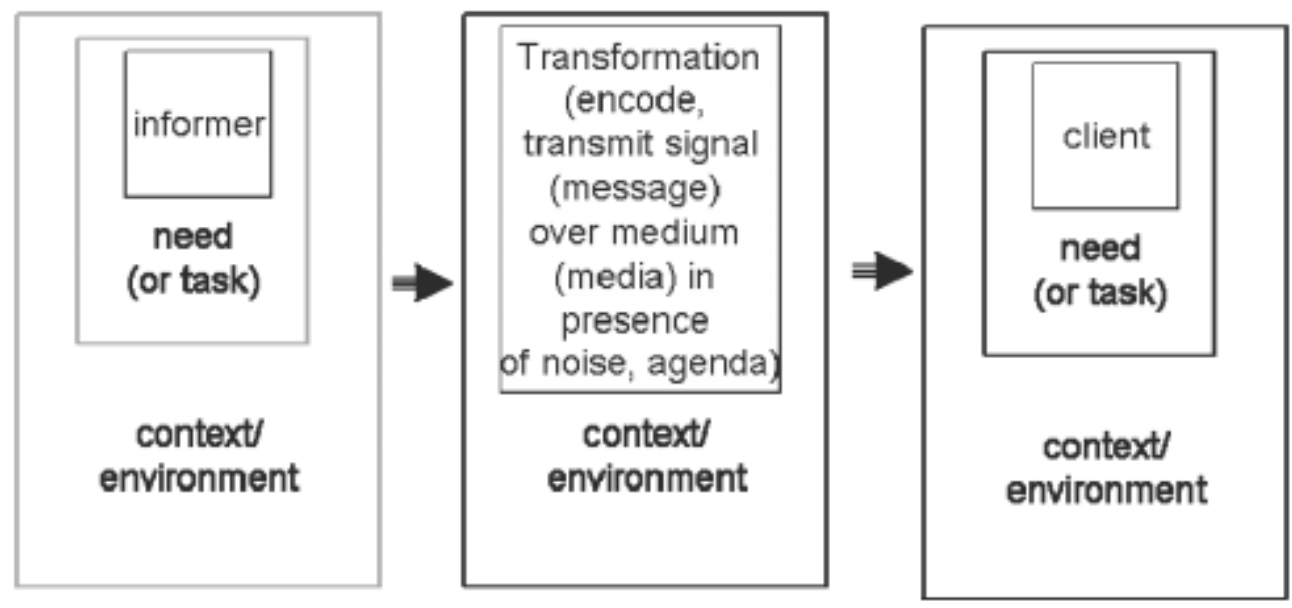

Figure 4. Model of the Informing Science Process, from Cohen (2009)

For purposes of this research we focused on the third or client portion of the model. Our first task was to fit dispositional, situational, and institutional barriers within this framework. Clearly institutional barriers reside in the environment and dispositional barriers reside in the client. Our problem at this point was situational barriers. While these initiate from within the environment, it is the client or student's reaction to them, through cognitive bias, that gives them their influence, as shown in Figure 5.

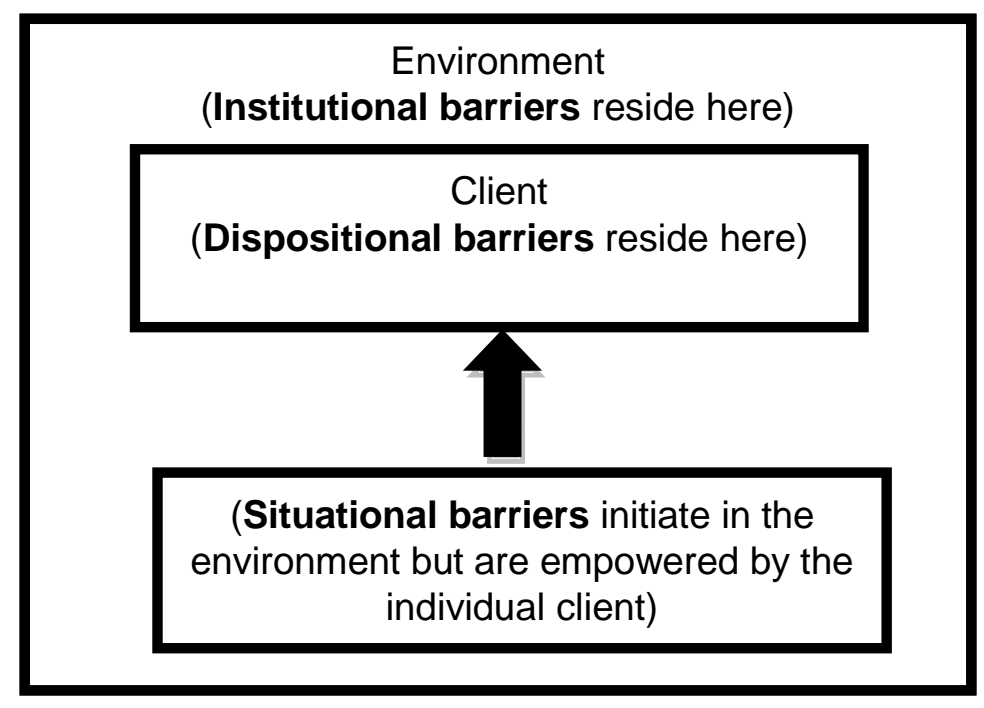

Figure 5. Client portion of the informing science model, showing 3 major barrier types 


\section{Summary of Relationships}

If one considers the conceptual model in Figure 5 and the Framework of Barriers in Table 8 in terms of mathematical modeling, the following relationships become apparent:

Dispositional filter $=\mathrm{f}$ (student orientation, cognitive bias)

where student orientation $=$

f (self-image, perceived program value, image of sender, image of channel)

Situational filter $=\mathrm{f}($ perceived environment $)$

where perceived environment $=$

$\mathrm{f}$ (prior knowledge, cultural considerations, learning environment, personal environment)

Institutional filter $=\mathrm{f}$ (cost, weather, support, technology)

From these relationships, we develop the model of client-specific filters to andragogical communication shown in Figure 6. This figure is but a portion of the entire informing process shown at a macro level in Figure 4. Notice that the goal here is successful learning. While the outcome of the filters or barriers in this model definitely influence successful learning, it is important to consider that we are only concerned in this paper with the client or student side of learning. There are clearly many other variables to consider relating to the faculty member and the channel.

\section{Evaluation of the Model}

As previously stated, Gill (2011b) notes that the defining characteristic of a conceptual scheme is usefulness, which he defines as the intersection of three characteristics: relevant, acceptable, and potentially actionable. How well, then, does the model developed in this paper meet these standards? With regard to relevance, the conceptual scheme in Figure 6 is based on an amalgamation of recent research into the fields of informing science and adult learning. This foundation ensures the model is relevant to students and teachers involved in higher education. With regard to acceptance, we are hopeful that the process of peer review of this paper will indicate that there is agreement on the potential value of the model distilled here. The last characteristic to meet is potentially actionable. To address this characteristic, a small group of faculty, using the conceptual scheme in Figure 6, was able to develop extensive lists of specific actions that students, faculty, and institutions could take to overcome or minimize barriers. These lists are detailed in $A p$ pendix A, Actions students can take to alleviate barriers to adult learning, and Appendix B, Actions faculty and institutions can take to alleviate barriers to adult learning. The sheer size of these two lists lends credence to the argument that the conceptual scheme presented here is indeed actionable. 


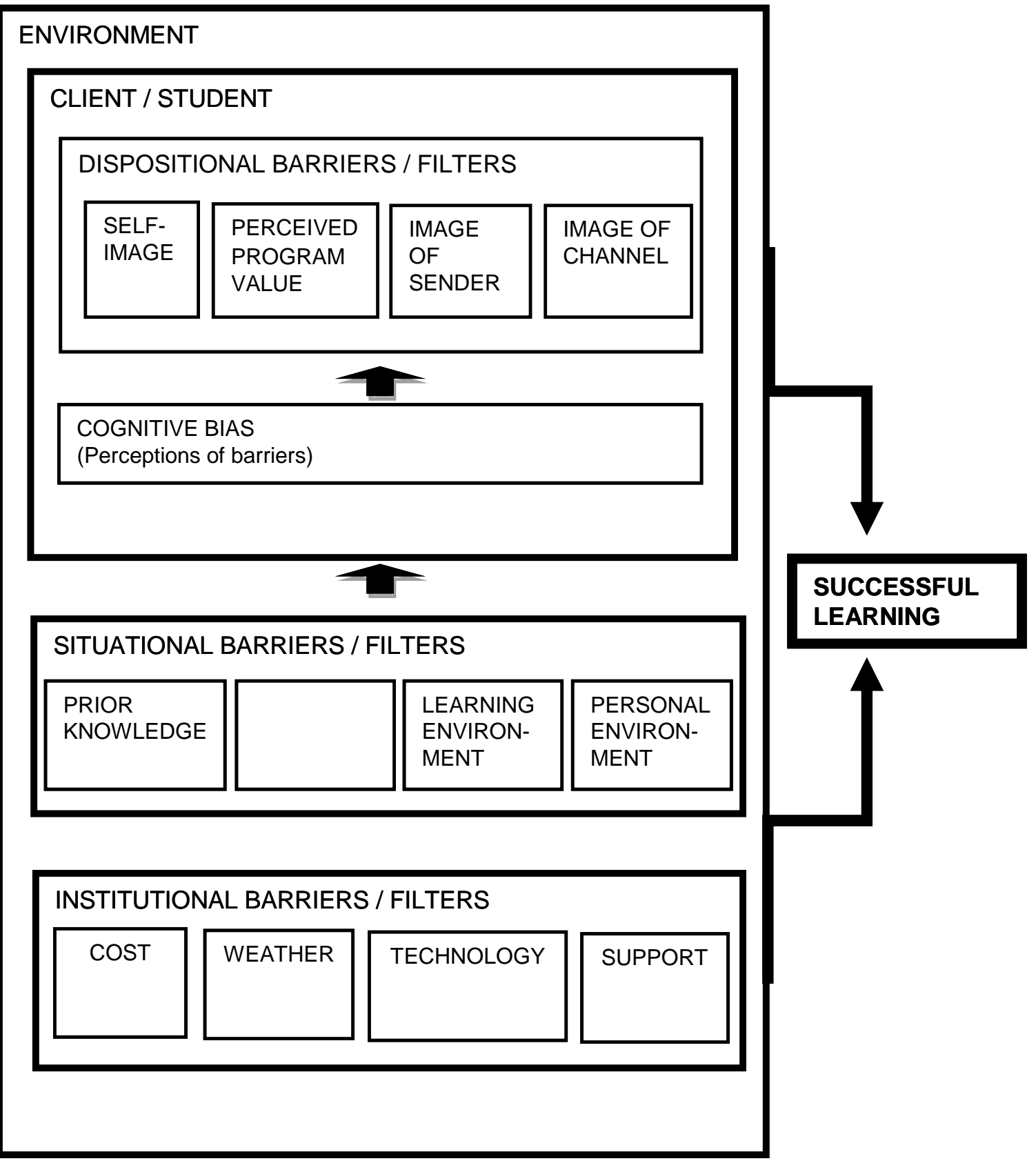

Figure 6. Conceptual Scheme of Client-Side Barriers to Informing University Students

In this paper, we have developed a client-side conceptual scheme of informing that is specific to the domain of andragogical learning. We now consider how this model compares with earlier informing science models. When we compare our conceptual scheme of client-side barriers to informing university students (Figure 6) with Cohen's (2009) model of the informing science process (Figure 4), we see our conceptual scheme as a specific application of Cohen's more general case. Comparison of our scheme with Gill's generic model of the client side of informing (Figure 2) is somewhat more complex since the two approaches are quite different. While our andragogical model has successful learning as its goal, Gill's broader Client Resonance Model has as its result three separate levels of task specific knowledge developed within the client. Perhaps most significantly, while our conceptual scheme focuses on specific prejudices and predispositions within the client (self-image, cultural considerations, etc.) and specific external forces 
(cost, weather, technology, etc.), Gill's broader model associates different filters with different potential effects on the information being received (attention filter, motivation filter, etc.) Thus, these two models are complimentary without being overlapping.

Much work remains to be done. The research presented here is narrow in scope, focused solely on the adult client or student. The conceptual scheme we have developed needs to be enhanced by the addition of informer and channel related barriers. Further, even if these informer and channel barriers were added, the scheme would represent only adult education and not the entire field of education. Most significantly, this conceptual scheme is just one of many that could be developed for a broad range of disciplines. We are hopeful that by developing a new view of adult education as an informing science, we will encourage others to look beyond the walls of their disciplines and investigate how informing science can inform and enrich their research, as well as how their discipline can inform and enrich the field of informing science. This hope is not new; it is consistent with Cohen's (1999) original paper conceptualizing the field of informing science as a transdiscipline.

\section{Conclusion}

Our original goal for this paper was to combine education and informing science research to develop a conceptual model with the ability to assist university professors and students in identifying and overcoming barriers to informing. Contributions of this work go beyond this and include ferreting out 24 barriers to andragogical learning from the education literature, identifying 12 underlying constructs, and incorporating the concept of client side institutional, situational, and dispositional barriers into the Informing Science Model. In the process of doing this, we developed the Educational Barrier Matrix, which we believe will have broader applications in both education and informing science. Further, in the process of defending the usefulness of the conceptual model presented here, we also distilled an extensive list of actions that students, faculty, and institutions can use as a starting point for overcoming barriers to andragogical learning. Finally, the development of a client-side model of informing that is specific to the domain of andragogical learning likely will have additional applications in other informing realms, including other levels of education and other disciplines. Despite all these contributions, we believe the greatest contribution of this work may be its viewing of education research, not as a silo onto itself, but as one facet of informing. We invite others to look at their disciplines to develop their own conceptual schemes of the informing science process.

\section{References}

Bain, K. (2004). What the best college teachers do. Cambridge, MA: Harvard University Press.

Bednar, P. M., \& Welsh, C. (2008). Bias, misinformation and the paradox of neutrality. Informing Science: the International Journal of an Emerging Transdiscipline, 11, 85-106. Retrieved from http://www.inform.nu/Articles/Vol11/ISJv11p085-106Bednar528.pdf

Blum, K. D. (1999). Gender differences in asynchronous learning in higher education: Learning styles, participation barriers and communication patterns. Journal of Asynchronous Learning Networks, 3(1).

Burge, L. (1988). Beyond andragogy: Some explorations for distance learning design. Journal of Distance Education, 3(1), 5-23.

Cohen, E. B. (1999). Reconceptualizing information systems as a field of the transdiscipline informing science: From ugly duckling to swan. Journal of Computing and Information Technology, 7(3), 213-219.

Cohen, E. B. (2000a). Failure to inform: Errors in informing systems. AMCIS 2000 Proceedings, 10571061. 
Cohen, E. B. (2000b, September). Informing and misinforming. Speech presented at the 1st International Congress of the OOICTL Academy on Teaching, Learning \& Classroom/Course Management in Business and Related Areas, Shreveport, LA.

Cohen, E. B. (2007). Informing and misinforming: The practice and science of using technology to inform, misinform, \& disinform. Israel Association for Information Systems 2007 Conference: Bar-Ilan University.

Cohen, E. B. (2009). A philosophy of informing science. Informing Science: the International Journal of an Emerging Transdiscipline, 12, 1-15. Retrieved from http://www.inform.nu/Articles/Vol12/ISJv12p001-015Cohen399.pdf

Cranton, P. (2002). Teaching for transformation. New Directions for Adult and Continuing Education, 93(Spring). Retrieved from EBSCOhost database.

DeVito, K. M. (2009). Implementing adult learning principles to overcome barriers of learning in continuing higher education programs. Online Journal of Workforce Education and Development, 3(4). Retrieved from http://opensiuc.lib.siu.edu/cgi/viewcontent.cgi?article=1058\&context=ojwed\&sei$\underline{\text { re- }}$ dir=1\&referer=http\%3A\%2F\%2Fscholar.google.com\%2Fscholar\%3Fhl\%3Den\%26q\%3Dimplementin g\%2Badult\%2Blearning\%2Bprinciples\%2Bde\%2Bvito\%26btnG\%3DSearch\%26as_sdt\%3D0\%252C1 4\%26as_ylo\%3D\%26as_vis\%3D0\#search=\%22implementing\%20adult\%20learning\%20principles\%2 0de\%20vito\%22

Gackowski, Z. J. (2006). Quality of informing: Bias and disinformation philosophical background and roots. Issues in Informing Science and Information Technology, 3, 731-744.

Gackowski, Z. J. (2010). Informing science as a discipline: An initial proposal. Informing Science: the International Journal of an Emerging Transdiscipline, 13, 165-175. Retrieved from http://www.inform.nu/Articles/Vol13/ISJv13p165-175Gackowski565.pdf

Galusha, J. M. (1997). Barriers to learning in distance education. Retrieved from http://www.infrastruction.com/articles.htm

Gill, T. G. (2008a). Structural complexity and effective informing. Informing Science: the International Journal of an Emerging Transdiscipline, 11, 253-279. Retrieved from http://www.inform.nu/Articles/Vol11/ISJv11p253-279Gill223.pdf

Gill, T. G. (2008b). The single client resonance model: Beyond rigor and relevance. Informing Science: the International Journal of an Emerging Transdiscipline, 11, 281-310. Retrieved from http://www.inform.nu/Articles/Vol11/ISJv11p281-310Gill222.pdf

Gill, T. G. (2010). Informing business: Research and education on a rugged landscape. Santa Rosa, CA: Informing Science Press.

Gill, T. G. (2011a, June). InSITE Conference Keynote Address. Speech presented at the 2011 Informing Science \& IT Education Conference, Novi Sad, Serbia.

Gill, T. G. (2011b). When what is useful is not necessarily true: The underappreciated conceptual scheme. Informing Science: the International Journal of an Emerging Transdiscipline, 14, 1-32.

Halhoun, I. A., \& Hestenes, D. (1985). The initial knowledge state of college physics. American Journal of Physics, 53, 1043-1055.

Jamieson, K., \& Hyland, P. (2006). Good intuition or fear and uncertainty: The effects of bias on information systems selection decisions. Informing Science: the International Journal of an Emerging Transdiscipline, 9, 49-69.

Jarvis, P. (1995) Adult and continuing education. London: Routledge.

Kalyuga, S. (2011). Informing: A cognitive load perspective. Informing Science: the International Journal of an Emerging Transdiscipline, 14, 33-45. Retrieved from http://www.inform.nu/Articles/Vol14/ISJv14p033-045Kalyuga586.pdf 
Informing Science and Andragogy

Kimmel, S. B., \& McNeese, M. N. (2006). Barriers to business education: Motivating adult learners. Journal of Behavioral and Applied Management, 7(3), 293-303.

Klein, H. J., Noe, R. A., \& Wang, C. (2006). Motivation to learn and course outcomes: The impact of delivery mode, learning goal orientation, and perceived barriers and enablers. Personnel Psychology, 59, 665-702

Knight, L. V., Hop, J. D., \& Steinbach, T. A. (2012, March). Incorporating the principles of andragogy in an online learning environment. Proceedings of the $48^{\text {th }}$ Annual MBAA International Conference, Information Systems and Quantitative Methods.

Knowles, M. (1968). Andragogy, not pedagogy. Adult Leadership, 16(10), 350-352,386.

Knowles, M. (1973). The modern practice of adult education: From pedagogy to andragogy. Cambridge, New Jersey: Cambridge Adult Education.

Lang, M. (2003). Communicating academic research findings to IS Professionals: An analysis of problems. Informing Science: the International Journal of an Emerging Transdiscipline, 6, 12-29. Retrieved from http://www.inform.nu/Articles/Vol6/v6p021-029.pdf

McCarthy, R. R., \& Berger, J. (2008). Moving beyond cultural barriers: Successful strategies of female technology education teachers. Journal of Technology Education, 19(2), 65-79.

Mezirow, J. (1997). Transformative learning: Theory to practice. New Directions for Adult and Continuing Education, 74, 5-12.

Mitchell, S. (2006). Socratic dialogue, the humanities and the art of the question. Arts and Humanities in Higher Education: An International Journal of Theory, Research and Practice, 5(2), 181-197.

Morris, L. K., \& Daniel, L. G. (2008). Perceptions of a chilly climate: Differences in traditional and nontraditional majors for women. Research in Higher Education, 49(3), 256-273.

Muilenburg, L.Y., \& Berge, Z. L. (2005). Student barriers to online learning: A facto analytic study. Distance Education, 26(1), 29-48.

Mungania, P. (2003). The seven e-learning barriers facing employees. Retrieved from http://www.aerckenya.org/docs/ElearningReport.pdf

Politser, P. (2008). Neuroeconomcs. Oxford, UK: Oxford University Press.

Reischmann, J. (2005). Andragogy: History, meaning, context, function. In L.M. English (Ed.), International encyclopedia of adult education (p. 58-63). Houndsville, NY: Palgrave Macmillan.

Rogers, C. R. (1969). Freedom to learn: A view of what education might become. Columbus, Ohio: C.E. Merrill Publishing Company.

Shenk, D. (1997). Data smog: Surviving the information glut. eBook: HarperCollins Publishers.

Silva, T., Cahalan, M., \& Lacierno-Paquet, N. (1998). Adult education participation decisions and barriers: Review of conceptual frameworks and empirical studies. U.S. Department of Education. National Center for Education Statistics. Washington, D.C. Working Paper No. 98-10. Retrieved from http://nces.ed.gov/pubsearch/pubsinfo.asp?pubid=9810

Smith, M. K. (2011a) Andragogy. The encyclopedia of informal education, Retrieved from http://www.infed.org/lifelonglearning/b-andra.htm.

Smith, M. K. (2011b) Learning theory. The encyclopedia of informal education. Retrieved from www.infed.org/biblio/b-learn.htm

Stahl, B. C. (2006). On the difference or equality of information, misinformation and disinformation: A critical research perspective. Informing Science: the International Journal of an Emerging Transdiscipline, 9, 83-96. Retrieved from http://www.inform.nu/Articles/Vol9/v9p083-096Stahl65.pdf

Taylor, T., \& Rose, J. (2005). Bridging the divide: Older learners and new technologies. A paper presented to the AVTEC conference. 
Timarong, A., Temaungil, M., \& Sukrad, W. (2002). Adult learning and learners. PREL Briefing Paper. Pacific Resources for Education and Learning, Retrieved from http://www.eric.ed.gov/PDFS/ED469013.pdf

U.S. Department of Education. National Center for Education Statistics. (2007). The condition of education. Retrieved from http://nces.ed.gov/programs/coe/indicator_aed.asp

Vella, J. (2002). Learning to listen, learning to teach, the power of dialogue in educating adults. San Francisco, CA: Jossey Bass Higher Education Series.

\section{Appendix A. Actions students can take to alleviate client-side barriers to adult learning}

\begin{tabular}{|c|c|}
\hline BARRIER & POSSIBLE STUDENT ACTIONS TO ALLEVIATE BARRIER \\
\hline $\begin{array}{l}\text { Classes not avail- } \\
\text { able }\end{array}$ & $\begin{array}{l}\text { - Use transfer credits from other institutions. Example: Community col- } \\
\text { leges are currently being promoted by the U.S. government as a cost- } \\
\text { effective approach to education } \\
\text { - Meet with adviser early in program and regularly thereafter to plot out } \\
\text { plan based on past offering patterns or announced schedule }\end{array}$ \\
\hline $\begin{array}{l}\text { Institution technol- } \\
\text { ogy not functioning } \\
\text { correctly }\end{array}$ & $\begin{array}{l}\text { - Alert university tech staff and instructor by following prescribed proce- } \\
\text { dures } \\
\text { - Take advantage of institution's technology support for students } \\
\text { - Attend any optional university training available }\end{array}$ \\
\hline $\begin{array}{l}\text { Difficult to access } \\
\text { required informa- } \\
\text { tion }\end{array}$ & $\begin{array}{l}\text { - Provide feedback to tech staff and instructor by following prescribed pro- } \\
\text { cedures } \\
\text { - Take advantage of institution's technology support for students } \\
\text { - Network with other students }\end{array}$ \\
\hline $\begin{array}{l}\text { Lack of institutional } \\
\text { support for tutoring }\end{array}$ & $\begin{array}{l}\text { - Create a study group } \\
\text { - Network with other students } \\
\text { - Make active, regular use of professor's office hours }\end{array}$ \\
\hline $\begin{array}{l}\text { Lack of technical } \\
\text { assistance }\end{array}$ & $\begin{array}{l}\text { - Create a study group } \\
\text { - Network with other students } \\
\text { - Make active, regular use of professor’s office hours }\end{array}$ \\
\hline $\begin{array}{l}\text { Lack of institutional } \\
\text { guidance. }\end{array}$ & $\begin{array}{l}\text { - Meet with adviser every term } \\
\text { - Seek out faculty in subject area of interest and meet with them regularly }\end{array}$ \\
\hline $\begin{array}{l}\text { Cultural value of } \\
\text { education }\end{array}$ & • Network with other students of the same cultural background \\
\hline $\begin{array}{l}\text { High cost of educa- } \\
\text { tion }\end{array}$ & - Exploit sources for aid inside and outside of the university \\
\hline Weather & $\begin{array}{l}\text { - Be flexible in use of mass transit when weather starts to negatively affect } \\
\text { commuting }\end{array}$ \\
\hline Family obligations & - Develop a bartering system to trade babysitting, adult day care, rides, etc. \\
\hline $\begin{array}{l}\text { Family value for } \\
\text { education }\end{array}$ & $\begin{array}{l}\text { - Seek out mentors who once were in a similar position } \\
\text { - Identify and communicate regularly with supportive family members }\end{array}$ \\
\hline $\begin{array}{l}\text { Insufficient entry } \\
\text { level knowledge }\end{array}$ & $\begin{array}{l}\text { - Meet with instructor at start of course specifically to honestly assess } \\
\text { course readiness }\end{array}$ \\
\hline
\end{tabular}




\begin{tabular}{|c|c|}
\hline BARRIER & POSSIBLE STUDENT ACTIONS TO ALLEVIATE BARRIER \\
\hline Health concerns & $\begin{array}{l}\text { - Be responsible in addressing health problems } \\
\text { - Use university resources for physical and mental health }\end{array}$ \\
\hline $\begin{array}{l}\text { Inconvenient class } \\
\text { time }\end{array}$ & - Take online courses or transfer courses from another institution \\
\hline $\begin{array}{l}\text { Inconvenient loca- } \\
\text { tion }\end{array}$ & - Take online courses or transfer courses from another institution \\
\hline $\begin{array}{l}\text { Lack of employer } \\
\text { support }\end{array}$ & $\begin{array}{l}\text { - Seek opportunities to demonstrate acquired knowledge to employer } \\
\text { - Negotiate flex time }\end{array}$ \\
\hline Lack of time & $\begin{array}{l}\text { - Enroll in time management seminar } \\
\text { - Set aside specific time for study and block it out on calendar }\end{array}$ \\
\hline $\begin{array}{l}\text { Transportation } \\
\text { problems }\end{array}$ & $\begin{array}{l}\text { - Ride share with other students } \\
\text { - Minimize commuting by taking online or hybrid courses }\end{array}$ \\
\hline $\begin{array}{l}\text { Insufficient com- } \\
\text { puter literacy }\end{array}$ & $\begin{array}{l}\text { - Identify a computer expert among family and friends } \\
\text { - Take online tutorials or attend seminars on technology use }\end{array}$ \\
\hline $\begin{array}{l}\text { Entering non- } \\
\text { traditional role }\end{array}$ & • Identify potential mentor and establish a relationship \\
\hline $\begin{array}{l}\text { Individual percep- } \\
\text { tion of learning } \\
\text { process }\end{array}$ & $\begin{array}{l}\text { - Set aside a time and place for study } \\
\text { - Make study time more enjoyable by having a favorite beverage, playing } \\
\text { relaxing music, and eliminating distractions } \\
\text { - Reward yourself after study time with a pleasurable activity }\end{array}$ \\
\hline $\begin{array}{l}\text { Accessibility due to } \\
\text { age }\end{array}$ & $\begin{array}{l}\text { - Learn how to increase font size, use screen readers or speech recognition } \\
\text { technology } \\
\text { - Network with students who consider themselves in similar age-based } \\
\text { situation }\end{array}$ \\
\hline Classes not relevant & - See adviser and reassess program choice \\
\hline $\begin{array}{l}\text { Confidence level of } \\
\text { student }\end{array}$ & $\begin{array}{l}\text { - Seek out tutoring and networking groups } \\
\text { - Develop one or two fellow students as a support group } \\
\text { - Be persistent and recognize that you are building experience } \\
\text { - Spend a few moments after study time looking over your accomplish- } \\
\text { ments and congratulating yourself }\end{array}$ \\
\hline Personal maturity & $\begin{array}{l}\text { - Develop a network of fellow students who are responsible and mature } \\
\text { - Consider postponing education }\end{array}$ \\
\hline $\begin{array}{l}\text { Program duration } \\
\text { seems too long }\end{array}$ & $\begin{array}{l}\text { - Consider shorter programs that would enable one to get a credential, that } \\
\text { can be built upon later (Example: Consider certificate programs or earn } \\
\text { an AA before a BA) } \\
\text { - Take CLEP exams } \\
\text { - At the end of each term, celebrate your accomplishments as milestones }\end{array}$ \\
\hline $\begin{array}{l}\text { Competing informa- } \\
\text { tion }\end{array}$ & - Seek clarification from instructor or other sources \\
\hline
\end{tabular}

Note: Appendix A and B are designed to demonstrate that the conceptual scheme presented in this paper is actionable. While not intended to be comprehensive, they nonetheless can be useful to those wishing to develop plans to lessen barriers to adult education. 


\section{Appendix B. Actions institutions or faculty can take to alleviate client side barriers to adult learning}

\begin{tabular}{|c|c|}
\hline BARRIER & $\begin{array}{l}\text { POSSIBLE INSTITUTION OR FACULTY ACTIONS TO ALLEVI- } \\
\text { ATE BARRIER }\end{array}$ \\
\hline $\begin{array}{l}\text { Classes not avail- } \\
\text { able }\end{array}$ & $\begin{array}{l}\text { - Review and modify course scheduling based on prerequisites and required } \\
\text { courses } \\
\text { - Provide schedule announcements to students for planning purposes } \\
\text { - Build in flexibility into degree requirements }\end{array}$ \\
\hline $\begin{array}{l}\text { Institutional tech- } \\
\text { nology not func- } \\
\text { tioning correctly }\end{array}$ & $\begin{array}{l}\text { - Follow best practices for IT } \\
\text { - Use help desk escalation } \\
\text { - Provide notices to community regarding problem / solution } \\
\text { - Make an electronic trouble ticket system readily available for student use } \\
\text { - Provide a text (or phone) based help line for students } \\
\text { - Give high priority to addressing student technical problems } \\
\text { - Provide short, self-paced online learning opportunities addressing the most } \\
\text { common student problems } \\
\text { - Expand hours of availability for student help }\end{array}$ \\
\hline $\begin{array}{l}\text { Difficult to access } \\
\text { required informa- } \\
\text { tion }\end{array}$ & $\begin{array}{l}\text { - Employ good navigation design techniques } \\
\text { - Make an electronic trouble ticket system readily available for student use } \\
\text { - Provide a text (or phone) based help line for students } \\
\text { - Give high priority to addressing student technical problems } \\
\text { - Provide short, self-paced online learning opportunities addressing the most } \\
\text { common student problems } \\
\text { - Expand hours of availability for student help } \\
\text { - Provide FAQ list }\end{array}$ \\
\hline $\begin{array}{l}\text { Lack of institution } \\
\text { support for tutor- } \\
\text { ing }\end{array}$ & $\begin{array}{l}\text { - Develop and support a tutoring center for required and most problematic } \\
\text { courses } \\
\text { - Develop more specific course materials, anticipating and addressing stu- } \\
\text { dent problems } \\
\text { - Provide online tutoring }\end{array}$ \\
\hline $\begin{array}{l}\text { Lack of technical } \\
\text { assistance }\end{array}$ & $\begin{array}{l}\text { - Develop and support a help desk } \\
\text { - Provide online tutoring } \\
\text { - Provide FAQ list }\end{array}$ \\
\hline $\begin{array}{l}\text { Lack of institu- } \\
\text { tional guidance }\end{array}$ & $\begin{array}{l}\text { - Develop, display and routinely update information } \\
\text { - Follow best practices for advising } \\
\text { - Schedule advising time to meet student schedules } \\
\text { - Provide online advising }\end{array}$ \\
\hline $\begin{array}{l}\text { Cultural value of } \\
\text { education }\end{array}$ & $\begin{array}{l}\text { - Provide university support groups for different cultural backgrounds } \\
\text { - Develop outreach programs for various cultures }\end{array}$ \\
\hline $\begin{array}{l}\text { High cost of edu- } \\
\text { cation }\end{array}$ & $\begin{array}{l}\text { - Provide information on all possible sources of aid, grants and scholarships, } \\
\text { including those external to the university }\end{array}$ \\
\hline
\end{tabular}




\begin{tabular}{|c|c|}
\hline BARRIER & $\begin{array}{l}\text { POSSIBLE INSTITUTION OR FACULTY ACTIONS TO ALLEVI- } \\
\text { ATE BARRIER }\end{array}$ \\
\hline Weather & $\begin{array}{l}\text { - Subsidize mass transit options for students including bus passes or univer- } \\
\text { sity-provided van pools from areas of heavy student concentration }\end{array}$ \\
\hline Family obligations & $\begin{array}{l}\text { - Provide on-site child care with supervision for older children and also in- } \\
\text { cludes emergency, short term child care }\end{array}$ \\
\hline $\begin{array}{l}\text { Family value for } \\
\text { education }\end{array}$ & $\begin{array}{l}\text { - Promote family activities } \\
\text { - Develop an initiative to educate the families of first generation college } \\
\text { students }\end{array}$ \\
\hline $\begin{array}{l}\text { Insufficient entry } \\
\text { level knowledge }\end{array}$ & • Provide assessment tests \\
\hline Health concerns & $\begin{array}{l}\text { - Promote wellness by making students aware of available mental and } \\
\text { physical health care facilities }\end{array}$ \\
\hline $\begin{array}{l}\text { Inconvenient class } \\
\text { time }\end{array}$ & • Provide online or hybrid courses \\
\hline $\begin{array}{l}\text { Inconvenient class } \\
\text { location }\end{array}$ & - Provide online or hybrid courses \\
\hline $\begin{array}{l}\text { Lack of employer } \\
\text { support }\end{array}$ & - Invite major student employers to campus \\
\hline Lack of time & - Offer time management seminars \\
\hline $\begin{array}{l}\text { Transportation } \\
\text { problems }\end{array}$ & $\begin{array}{l}\text { - Subsidize mass transit options for students including bus passes or univer- } \\
\text { sity-provided van pools from areas of heavy student concentration } \\
\text { - Create an optional carpool database } \\
\text { Create an emergency ride sharing database }\end{array}$ \\
\hline $\begin{array}{l}\text { Insufficient com- } \\
\text { puter literacy }\end{array}$ & • Online tutorials \\
\hline $\begin{array}{l}\text { Entering non- } \\
\text { traditional role }\end{array}$ & $\begin{array}{l}\text { - Profile successful role models } \\
\text { - Develop mentoring program }\end{array}$ \\
\hline $\begin{array}{l}\text { Individual percep- } \\
\text { tion of learning } \\
\text { process }\end{array}$ & $\begin{array}{l}\text { - Address multiple learning styles } \\
\text { - Update materials and teaching methods } \\
\text { - Promote best practices in teaching } \\
\text { - Leverage current technology in teaching }\end{array}$ \\
\hline $\begin{array}{l}\text { Accessibility due } \\
\text { to age }\end{array}$ & $\begin{array}{l}\text { - Create opportunities for development of peer groups of similar ages } \\
\text { - Make training available to those less familiar with technology } \\
\text { - Make training available to those with accessibility issues }\end{array}$ \\
\hline $\begin{array}{l}\text { Classes not rele- } \\
\text { vant }\end{array}$ & $\begin{array}{l}\text { - Institute regular curriculum review } \\
\text { Emphasize relevance in courses }\end{array}$ \\
\hline $\begin{array}{l}\text { Confidence level } \\
\text { of student }\end{array}$ & • Develop mentoring programs \\
\hline Personal maturity & Provide seminars on time management, financial fitness, study habits \\
\hline $\begin{array}{l}\text { Program duration } \\
\text { too long }\end{array}$ & $\begin{array}{l}\text { - Define milestones in longer programs and recognize the meeting of the } \\
\text { milestones as they occur }\end{array}$ \\
\hline $\begin{array}{l}\text { Competing infor- } \\
\text { mation }\end{array}$ & $\begin{array}{l}\text { - Create a safe atmosphere to encourage students to express diverging views } \\
\text { - Recognize diverging views when presenting material }\end{array}$ \\
\hline
\end{tabular}


Note: Appendix A and B are designed to demonstrate that the conceptual scheme presented in this paper is actionable. While not intended to be comprehensive, they nonetheless can be useful to those wishing to develop plans to lessen barriers to adult education. Some of the material in Appendix B previously appeared in Knight et al. (2012).

\section{Biographies}

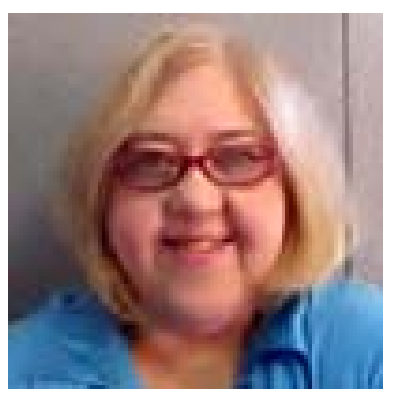

Linda V. Knight, $\mathrm{PhD}$, teaches and conducts research in the area of Information Technology project management and education. Editorin-Chief of the Journal of Information Technology Education, she is also former Associate Editor of the Information Resources Management Journal, as well as Past President and Fellow of the Society for the Advancement of Information Systems, an affiliate of MBAA International. She has served on the Editorial Advisory Board of the Journal of Cases on Information Technology, and as a member of the Information Resources Management Association Executive Council. A Fellow of the Informing Science Institute, she also served 5 years on MBAA International's Executive Board, including a term as President. An entrepreneur and IT consultant, she has held industry positions in IT management and quality assurance management, and served over seven years as Associate Dean. In addition to a Ph.D. from DePaul University, she holds an MBA and a bachelor's degree in mathematics, both from Dominican University.

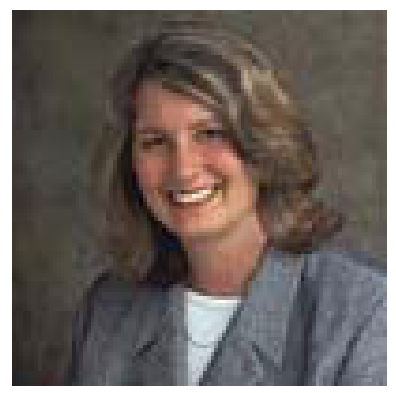

Theresa A. Steinbach, $\mathrm{PhD}$, is an Associate Professor at DePaul University’s College of Computing and Digital Media. Her research interests are IT education from primary grades through post-secondary level, program assessment and strategies for successful learning. Terry is an Editor for the Journal of Information Technology Education and currently serves as Secretary/Treasurer for the ACM's Special Interest Group for IT Education. She has received NSF grants to implement programs to retain women in undergraduate computing degrees and to modify computer science curriculum to become more attractive to high school students. Prior to teaching full-time for DePaul, Terry owned her own consulting firm that specialized in maximizing technology for business growth and profits. Her client base included representatives from the banking and nursing home industries, accounting firms, mortgage bankers, park districts and other municipal entities, as well as small and mid-size retail businesses. In addition to a Ph.D. in Computer Science from DePaul University, she also holds an M.S. in Information Systems, an M.B.A. in Quantitative Economics and a B.A.

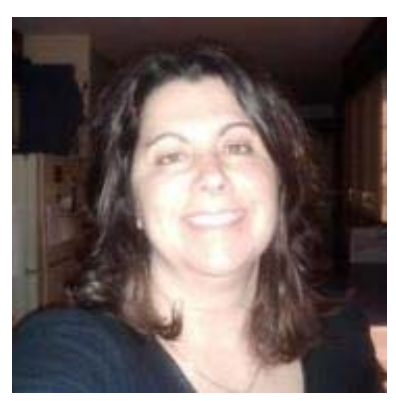

Jean Hop is an instructor and doctoral student at DePaul University's College of Computing and Digital Media with a particular interest in informing science as applied to education. A former financial analyst, systems analyst, and database programmer, she owned and operated her own business doing web design and development. Jean teaches both traditional classroom courses and online-only courses. She holds an MS in Computer Science from Illinois Institute of Technology and a BSC in Accountancy from DePaul University. 